\title{
Establishment and Optimization of Practical Teaching System in International Trade Specialty of Chinese Universities
}

\author{
Lin Guo \\ Hunan International Business Vocational College, Changsha, Hunan, 421000, China
}

Keywords: International trade, Practice, Teaching system, Establishment

\begin{abstract}
With the further economic development on a global scale, there is an incredibly huge demand from the society for professional talents, especially for talents majoring in international economics and trades. Nowadays, Chinese universities have worked out a wide range of practical teaching contents about international trade and commerce, such as the talents training program, the practical teaching plan and a comparatively mature theoretical teaching model. However, on account of many deficiencies of this practical teaching, it is necessary to establish a practical teaching system specially for international trade specialty.
\end{abstract}

\section{Introduction}

Practical teaching is known as the most important teaching method in Chinese universities at present, and only when it works with theoretical education together can they better serve the teaching system in Chinese universities and colleges. The content of practical teaching contains practical theory, practical verification theory, practical development theory, etc. Practical teaching can not only improve students' capability of practice and innovation, but also enhances their comprehensive competence, which benefits them a lot in job hunting. Thus, for students' further development of comprehensive competence and innovation capability, all the colleges and universities should constantly endeavor to perfect the practical teaching system and to make a better combination between practical teaching and theoretical education.

\section{The Current Status of Practical Teaching System in International Trade Specialty of Chinese Universities}

The Talents Training Target. According to Chinese universities' training plan for international trade talents, it has made several requirements for international trade and commerce majors, shown as below: it aims to cultivate talents proficient in international trade theory and knowledge, who is qualified to deal with international business and administrative affairs in diplomatic and economic sectors after graduation. The university pays attention to the education of basic theory and specialized knowledge about international economics and trades, and it offers students a specialized training on import and export trade, to explore their learning potentials and to help them with the acquisition of professional knowledge and the development of management skills during their undergraduate periods. After that, students are able to have a good command in several abilities as below: first of all, they have mastered the basic theory and knowledge about international trade and commerce during their 4-year study. Next, they have learned the methods and skills of import and export trades with the assistance from teacher. At last, universities manage to develop students' international business capability and foreign business management capability by offering relevant practical courses.

The Integration of Theoretical Education and Practical Teaching. The teaching forms of international trade specialty are mainly composed of two parts, the practical teaching and the theoretical education of which can be further divided into the compulsory course and the optional course based on students' needs. The compulsory theoretical teaching contains public elementary course, specialized course and other basic disciplinary lessons, while the optional course offers two kinds of options according to students' own needs, the elective lesson with limits and the other without them. In general, the number of compulsory courses is four times that of elective courses in Chinese universities and colleges. The practical teaching system of universities' international trade 
specialty covers a wide range of teaching contents, including the training of operational ability on practice base, the experiment teaching in lab, the guiding for graduation thesis and other practical training activities directed at students' capability of practice and manipulation.

The capabilities of practical operation and creation are two required professional competences for international economics and trade majors. The practical teaching system of international economics and commerce has been basically classified into three levels in Chinese universities and colleges: firstly, teachers should take better advantages of the lab to develop students' practical operation competence by the elementary education instructed both in classrooms and labs; next, universities ought to organize some school activities as to encourage students to be active in professional certification examinations, thus enhancing their specialized knowledge and competence; lastly, universities may cooperate with firms and enterprises to build a platform for students to learn from actual business and hands-on practice so that they could make progress in their professional capability of practice.

The Continuous Development in Hardware and Software Conditions of Practical Teaching System. In modern society, high-tech network technologies are gradually used in many universities' teaching application, leading to a range of more diversified teaching methods than before, such as web-based education, software teaching and multimedia teaching. Those methods have been widely applied, and the relevant hardware facilities in the lab that co-work with those information technologies have also been gradually improved and perfected, as to offer a more convenient teaching approach to all the universities' practical teaching. Besides, those constantly upgraded teaching hardware and software support universities' practical teaching with good equipments, excellent technologies and great sites.

\section{The Problems of Practical Teaching System in Universities' International Trade Specialty}

A Small Amount of Practical Courses and a Low Proportion of it in Total Credits. For the cultivation of international trade talents, Chinese universities and colleges lay great emphasis on the establishment of practical teaching system. However, due to a very small percentage of practical competence training in all course credits, the practical course enjoys no advantage in curriculum arrangement and only occupies it on a small scale, which finally results in the slow pace of class updating and the lagging behind world's advanced level. In China, international economics and trade specialty concentrates more on the theoretical instruction, which leads to the neglect of practical education on the other hand. "Great emphasis on wide ranges of theories" is now the main problem existing in the international trade specialty, in other words, universities focus too much on students' theoretical knowledge study while they pay too little attention to practical teaching so that the courses are limited in numbers, short in teaching time and low in proportion of total credits.

Necessity of Improving Teachers' Comprehensive Quality. The international trade and commerce specialty is a key program to develop interdisciplinary talents with high standards, and the nation is in regular demand for all-round international trade talents adept in excellent operational capability and theoretical knowledge. Therefore, a team of teachers with high comprehensive quality plays an important role in the cultivation of those well-qualified talents. In practical teaching, the requirement is even much stricter with teachers' comprehensive quality, that is to say, teachers should possess a great deal of specialized theoretical knowledge and practical teaching capability, as well as the rich experience in foreign trade practice. Nevertheless, universities in China are now exactly short of those teachers with high comprehensive quality, and therefore, to improve teachers' comprehensive quality is a significant prerequisite for the future development of international trade and commerce specialty.

The Lack of Scientific Reasonability and Preciseness in Test Evaluation System. The university's proposal for the establishment of test evaluation system is to some extent, beneficial to the assessment of country's comprehensive quality in international trade and commerce. The system could be divided into several parts as below: first of all, it is the assessment aimed at teachers with the high requirement for teachers' theoretical knowledge and practical teaching competence. However, 
in China, most universities and colleges introduce no preferential recruitment policy and title assessment in favor of teachers, leading to an unsatisfactory consequence that teachers act negatively when improving their comprehensive quality, since their great effort is not rewarded in those recruitment and assessment; The second assessment is the one for students that universities evaluate students' professional competence basically by examinations, oral defense and academic writing. But those aspects rely mainly on the evaluation of theoretical knowledge with little reference to practical assessment, such as the acquisition of professional certificate and the achievement of technological creation on practice base. In many Chinese universities, the credit for practice course is usually calculated by class period, which means students are able to get credits as long as they attend practical class. Hence, it lacks an efficient supervision system, and that's why students behave inactive in the class, among which plenty of them are even absent and stay out of it.

\section{The Principles of the Establishment of Practical Teaching System in International Trade and Commerce Specialty}

Target Orientation. The practical teaching system aims to co-work with universities' specialized talents training program. As a practical and internationalized specialty, the international trade specialty not only bears the responsibility to cultivate talents inconsistent with Chinese economic developing model, but also should possess a kind of innovative spirit and practical competence. Therefore, to build a practical teaching system with a specific target is a key factor to judge the scientific reasonability of it.

Systematization. The teaching system of international trade and commerce specialty ought to be improved and perfected based on teaching rules and cognition laws. In addition, according to the specialty's characteristics, it is recommended that building a practical teaching system with continuity should be achieved by connecting all parts of teaching activities together including their different statuses, functions and internal relations, and that is how systematization works in the whole process of international trade specialty's practical teaching system.

Integration. In the practical teaching of international trade and commerce, every teaching activity has to co-work with each other in harmony. Besides, according the specialized requirement and potential development for all-round talents, each link of teaching system should first of all, work in coordination and then strengthen their internal relations. The theoretical education and the practical education are greatly connected with each other, thus, it is necessary for teachers to combine teaching contents with course revolution to produce mutual support for these two kinds of education and to make the practical teaching independent from its counterpart but still with connections in the aspect of their teaching content. As for the establishment of practical teaching system, there should be a certain amount of standards to evaluate teaching contents, forms and methods, so every teaching giving practical courses ought to be aware of their target and responsibility, and have a specialized training plan and corresponding teaching syllabus.

\section{The Measures of Establishing Practical Teaching System of International Trade and Commerce Specialty}

Establishing a Systematic Teaching System. To begin with, it is about the curriculum design. Among a great deal of international trade talents, it is wise to lead them to the directed study with a specific focus on the market's demand, that is to say, to enhance their operational capability on the basis of their theoretical knowledge. The combination of theory and practice is of great significance for curriculum design, especially for an updated teaching content and a mature curriculum system. Practical course is actually about the application of theoretical knowledge into production practice and social activity. Each part of the practical teaching should co-work with its corresponding theoretical counterpart, but the original teaching form that lays practical teaching barely on the theoretical education should be absolutely changed and improved beyond question. In reality, it is better for teachers in international trade specialty to arrange relevant experiments to students considering their acquisition of specific theoretical knowledge. This is an effective way to cultivate 
students with comprehensive competence and innovative capability on account of the balance in curriculum design between theoretical class and practical class.

The second part is about teaching methods and techniques. This modified teaching system is totally against the original one in the terms of teaching models and techniques, in another word, it combines modern teaching methods with online assisted instruction software, to accelerate the construction of laboratory and off-campus experimental base, for a better practical teaching environment to students.

At last, here comes the teaching content. With the rapid development of Chinese economy, practical teaching contents have to constantly keep pace with it. If universities want to make some changes in the current theory-oriented teaching model, then they have to pay more attention to the teaching contents filled with practice, novelty and design. At present, Chinese practical teaching, is generally speaking, inferior to the theoretical education, which makes it hard to evoke students' enthusiasm and to complete the improvement of practical teaching. Hence, it is essential for the designers of practical teaching system to develop students' self-study capability, to arouse their interest in practical education, to make some changes in teaching contents and to combine basic knowledge, specialized techniques and comprehensive capability training together.

Building a Good Teaching Staff System. In the first place, it is to establish a team of excellent teachers with high quality, in details which means to enhance the training of teaching staffs, for a group of prominent teachers proficient in theoretical knowledge, practical capability and bilingual education. International trade and commerce is a key specialty in the field of nation's economy, thus, its teaching system has to put great emphasis on the training of teaching staffs. It is feasible to introduce foreign teachers into domestic universities in order to build a competitive teaching team with high stability, reasonability and comprehensiveness. Moreover, employing experienced talents as part-time teachers who have served in companies or enterprises before is also a brilliant idea to enhance the practical teaching for students. By that means, the teaching plan covers practical education assessment, internship experience and graduation project, and teachers are stimulated to take an active part in qualification attestation exams and interscholastic academic meetings, and to gain more practical teaching experience by working in companies.

The second step is to set up an incentive system that actively provides teachers with professional qualifications training. Then it also introduces the assessment of "double-certificated" teachers into the title rating, as to offer those teachers more learning opportunities and expenditures so that they are able to participate in off-campus professional training and practice program very often, and moreover, they will be rewarded with some incomes and subsidies according to their working hours.

Setting up a Complete Management System. Firstly, to establish a management institution means to set up an organization in the university, responsible for the practical teaching. At the same time, adding a liability system to make a distinct segregation of teachers' spectrums of duty and limitations of management. Thus, teachers at all levels have a clear idea about their own responsibility and can well cooperate with each other to perfect a complete and mature management institution.

Next, it should make relevant rules and regulations. In the process of practical teaching, it is necessary to work out an all-around education management model, including the corresponding teaching plan, the evaluation system for practical teaching and the management mode on practice base. Furthermore, it also contains the formulation of various teaching plans, such as teaching syllabus, internship plan and practical teaching guidance. At last, it is essential to make records about teaching implement, like practice records, internship reports and company’s feedback.

The third stage is to build a supervision system on implement, that is to say, to carry out a supervisory teaching directed at various management layers, based on the university's policies and regulations, for example, regularly but randomly checking on class teaching, auditing practical classes and inspecting teaching methods and contents. Moreover, it also imposes strict control on extremely formalized teaching and flawed teaching contents, and advocates the establishment of information institution collecting teaching archives and students' feedbacks. By that means, it is easy 
to detect problems in the teaching process and to act to them quickly, and that's mainly why it is an important part of practical teaching.

In the end, here comes the establishment of evaluation system. In fact, it refers to set up a system of examination and assessment on teaching. This system makes some alternations in the original evaluation system, which means that it not only aims at students' academic achievement but also their capability of innovation and practice. The introduction of society's requirement for international trade talents greatly encourages students to get more professional certificates, coupled with the grades of practical courses, which inspire them to learn their theoretical knowledge systematically and to enhance their manipulation training. All above together evoke students' enthusiasm and confidence in practical classes. Besides, such confidence could be largely strengthened by the reward of credits considering students' participation in academic reports, discipline competitions and scientific achievements.

\section{Conclusion}

Nowadays, with the ever-accelerated development in global economic business forms, the demand for international trade and commerce talents has been much greater than ever. Thus, universities should keep pace with society's need and make some changes in training method — - to set up an international base for talents cultivation. In this aspect, universities ought to maintain a blueprint consistent with the nations' development strategy and global economic pattern, as to improve the practical competence of international trade majors and to cultivate a group of prominent talents with high quality.

\section{References}

[1]Cai Sen. On the Cultivation of Practical Talents in International Trade and Commerce Based on the Market's Demand.Survey of Education (Feb. 15), 2015, (02):7-9.

[2]Guo Jingang. On the Cultivation Model of Practical Talents in International Trade and Commerce Based on the Market's Demand.Theory and Practice of Contemporary Education, 2015, (03):51-53.

[3]Tian Junfang. The Analysis of Quality Control System about Practical Teaching in International Economics and Trade Specialty.Journal of Changchun Education Institute, 2015,(06):108-109. 